\title{
Entrepreneurial Choice: Restoring a Relevant Antitrust Policy
}

Warren Grimes

Follow this and additional works at: https://scholarlycommons.law.case.edu/caselrev

Part of the Law Commons

\section{Recommended Citation}

Warren Grimes, Entrepreneurial Choice: Restoring a Relevant Antitrust Policy, 68 Case W. Rsrv. L. Rev. 58 (2017)

Available at: https://scholarlycommons.law.case.edu/caselrev/vol68/iss1/8

This Article is brought to you for free and open access by the Student Journals at Case Western Reserve University School of Law Scholarly Commons. It has been accepted for inclusion in Case Western Reserve Law Review by an authorized administrator of Case Western Reserve University School of Law Scholarly Commons. 
Case Western Reserve Law Review · Volume 68 · Issue $1 \cdot 2017$

\title{
ENTREPRENEURial CHOICE: Restoring A Relevant Antitrust POLICY
}

\author{
Warren Grimes
}

\begin{abstract}
Current antitrust orthodoxy focuses on short-term price/output factors. This increasingly criticized model does not adequately protect competition in industries in which individuals and small firms thrive. Small entrepreneurs may be efficient for a variety of reasons, including the incentives that flow from owner operation, the personal relationships that lead to superior service, or the strong creative component of the business. Despite advantages in efficiencies and superior willingness to innovate, small providers have been forced out of the market by intended or unintended effects of antitrust enforcement decisions and regulatory initiatives. This Article explores the concept of entrepreneurial choice and its application to small entrepreneurs. Recognizing the metric of entrepreneurial choice, along with consumer choice, is critical to protecting competition and restoring antitrust relevancy. To address these issues, the Article examines shortcomings in enforcement and regulatory policies in three critical industries-agriculture, healthcare, and communications and entertainment-and compares these industries to the wine and beer industries, where creative small entrepreneurs have a revitalized presence. This Article concludes by offering an approach for protecting efficient and in-demand small entrepreneurs while enhancing life choices for consumer and seller alike. In industries in which small entrepreneurs are efficient, this formula includes enhanced merger control, more vigorous antitrust enforcement to maintain open distribution, and greater tolerance for small seller collective actions needed to offset monopsony power.
\end{abstract}

$\dagger \quad$ Irving D \& Florence Rosenberg Professor of Law, Southwestern Law School. The author is grateful to participants in a Chicago Loyola Law School symposium and to Christine Bartholomew, Peter Carstensen, Larry Hannah, Stacy Mitchell, Albert Foer, John Kwoka, Christopher Sagers, and Spencer Waller for comments on earlier drafts. My thanks also to Greg Gundlach for his assistance in opening the door to the rich business-management literature addressing small firms and to Charlie Wang for his careful research on the beer and wine industries. 


\section{Contents}

INTRODUCTION . ... 62

I. Entrepreneurial Choice.............................................. 63

II. When Small Can Be Superior to Big .............................66 66

A. The Efficiencies of Small Businesses................................... 68

B. Creativity .......................................................... 71

C. Lifestyle Preferences for Entrepreneurial Independence ............. 72

III. Antitrust And Regulatory Failures in Three Critical

INDUSTRIES .................................................. 72

A. Agriculture ..................................................... 73

B. Healthcare ...................................................... 79

C. Communications and Entertainment........................... 85

IV. Why Small Firms Thrive in the Beer \& Wine Industries ...90

V. The Way Forward ............................................... 93

\section{INTRODUCTION}

Current antitrust orthodoxy focuses on short-term price and output factors in determining what constitutes an antitrust violation. ${ }^{1}$ Under this approach, mergers to tight oligopoly or oligopsony have been permitted and little attention has been paid to distribution restraints that stifle entry. Enforcement policies, it turns out, are particularly suspect when it comes to protecting individuals and small firms that efficiently perform in industries suited to small entrepreneurship. A focus on entrepreneurial choice - the flip side of protecting consumer

1. For criticism of this approach, see generally How the CHICAgo ScHool Overshot the Mark: The Effect of Conservative Economic ANAlysis ON U.S. Antitrust (Robert Pitofsky ed., 2008) (examining predominant interpretations of conservative economic theory); Jonathan Baker, Taking the Error Out of "Error Cost" Analysis: What's Wrong with Antitrust's Right, 80 ANTITRUsT L.J. 1, 7 (2015) (arguing that the application of the "error cost" framework relies on erroneous economic assumptions and yields "a non-interventionist bias" to any conclusions); Stacy Mitchell, View from the Shop-Antitrust and the Decline of America's Small Businesses, 61 AnTiTrust BuLL. 498, 502 (2016) (explaining how orthodox antitrust policy has undermined creative and innovative small businesses' ability to flourish and compete against larger firms); Lina M. Khan, Note, Amazon's Antitrust Paradox, 126 Yale L. J. 710, 717-46 (2017) (offering an extensive critique of the price/output model as background for assessment of Amazon). See also Einer Elhauge, Horizontal Shareholding, 129 HARV. L. REV. 1267, 1271-72 (2016) (explaining how institutional shareholders with substantial holdings in major rival firms in an industry reduce competition in oligopolistic industries and how this development may be linked to increasing concentration of wealth in fewer hands). 
choice - starkly highlights the shortcomings of a focus on price and output.

This Article examines how greater sensitivity to protection of the efficient individual entrepreneur or small firm - one that offers products and services in demand - can enhance efficiencies, promote innovation, provide needed guidance for regulatory initiatives, and increase the quality of life for both consumers and those who provide critical products and services. This approach has the added benefit of enhancing democratic values through dispersed economic power.

After first describing the concept of entrepreneurial choice in Part I, Part II focuses on the efficiencies and other advantages that explain the resilience of small firms and solo-practicing service providers. Part III examines some of the perverse effects of antitrust and regulation in three key industries: agriculture, healthcare, and telecommunications and entertainment. By way of contrast, Part IV examines why small providers have mounted a comeback in the beer and wine industries. This Article concludes that consumer and entrepreneurial choice should be given greater weight in setting antitrust and regulatory policies, particularly for industries suited for small entrepreneurs. Part V provides suggestions on how this might be done.

\section{Entrepreneurial Choice}

How do you buy what you eat? Do you shop primarily in supermarkets that are part of large regional or national chains? Would you prefer to have the choice of also buying from local farmers, whose products might be more expensive, but who offer enhanced freshness and genuine organic options?

How do you get your healthcare? Do you rely on an HMO or an insurance-company controlled medical plan that excludes some physicians from the network? Would you prefer to deal with a solopracticing or small-practice physician whom you trust and who has longstanding ties to your family?

What are your choices for home video entertainment? Do you rely on traditional cable programming supplied by large vertically integrated firms that control both distribution and content? Do you prefer the more open-ended options provided by the internet?

Answers to these questions will vary. Most of us, however, value choices and the opportunity to change our mind. Recognition that meaningful choices are a vital part of competition is hardly novel. In 1776, Adam Smith wrote that "the private interests and passions of men" lead them to allocate resources "as nearly as possible in the proportion which is most agreeable to the interest of the whole society." ${ }^{2}$

2. Adam Smith, An Inquiry Into the Nature and Causes of the Wealth of Nations 594-95 (Edwin Cannan ed., Mod. Lib. Ed. 1937) (1776). 
In focusing on how naturally occurring competition controlled allocation, Smith was cognizant of the preferences "of the whole society." 3 Both consumer and entrepreneurial choice were implicit in his approach. By 1890, the Sherman Act's proponents were not in the least reticent about their goal of protecting the small entrepreneur, particularly small farmers and ranchers - a theme that continues to be echoed in modern treatises. ${ }^{4}$

The antitrust approach to large firms has long focused on balancing their potential efficiencies against the risk of oligopolistic conductconduct that can directly affect downstream buyers and consumers. The oligopsony risks associated with large firms have received less attention. In 1966, Donald Turner, then Assistant Attorney General, addressed the issues raised by concentrated industries and focused on seller power and pricing. ${ }^{5}$ Turner did not mention buyer-power risks. Half a century later, although the literature has expanded our understanding of buyerpower abuses,${ }^{6}$ the Turner observations still reflect a mainstream antitrust focus on seller power.

In an earlier sentence in the same paragraph, Smith's focus on the well-being of society as a whole is also evident: "[T]he private interests and passions of individuals naturally dispose them to turn their stock towards the employments which in ordinary cases are most advantageous to the society." Id. at 594.

3. Id. at 595 .

4. See infra notes 37-43 and accompanying text (discussing the goals of the Sherman Act proponents). In their venerable treatise, Scherer and Ross describe the value of entrepreneurial choice: "A . . political merit of a competitive market is its freedom of opportunity. . . Individuals are free to choose whatever trade or profession they prefer, limited only by their own talent and skill and by their ability to raise the (presumably modest) amount of capital required." F.M. Scherer \& David Ross, Industrial Market Structure and ECONOMiC PeRformance 19 (3d ed. 1990).

5. An Interview with the Honorable Donald F. Turner, Assistant Attorney General in Charge of the Antitrust Division, 30 Antitrust L.J. 100, 103-04 (1966) ("[N]on-competitive pricing and other non-competitive behavior in oligopoly industries is a matter of serious concern, as indeed it has been for a long time."). It is possible that Turner used the words monopoly and oligopoly to cover both seller- and buyer-power issues, but such usage would also suggest the lack of focus on buyer-power issues.

6. See, e.g., Roger D. Blair \& Jeffrey L. Harrison, Monopsony: Antitrust LaW And Economics (1993); Clayton J. Masterman, Note, The Customer Is Not Always Right: Balancing Worker and Customer Welfare in Antitrust Law, 69 Vand. L. Rev. 1387, 1413 (2016); John B. Kirkwood, Powerful Buyers and Merger Enforcement, 92 B.U. L. REV. 1485, 1491-92 (2012); Peter C. Carstensen, Buying Power, Competition Policy, and Antitrust: The Competitive Effects of Discrimination Among Suppliers, 53 AnTiTRust Bull. 271, 276 (2008); Warren S. Grimes, Buyer Power and Retail Gatekeeper Power: Protecting Competition and the Atomistic Seller, 72 Antitrust L.J. 563, 563 (2005). 
On the demand side, the Supreme Court has recognized that one of the goals of competition law is the protection of consumer choice. ${ }^{7}$ Antitrust theorists have provided rich supportive commentary that describes the benefits of sensitivity to consumer choice issues. ${ }^{8}$ Protecting the choices and opportunities of a vulnerable atomistic seller would seem a natural corollary when the power lies not with the large seller but with large buyers who can coerce the small seller.

The connection between consumer choice and entrepreneurial choice is direct. If small firms that offer services and products consumers want are driven from the marketplace, consumer choice is undercut. When a relatively small craft brewer sells a popular product, but cannot survive because of lax antitrust enforcement or misguided regulatory policy, the loss in choice falls not only on the would-be craft brewer, but also on the consumer. Meaningful consumer choice exists when market structure allows for new entry and sustainability for small firms that offer what consumers want. Maintaining entrepreneurial choice is also linked to dynamic efficiency. A small firm with a novel idea appealing to consumers can have a difficult time sustaining its entry if large existing competitors can engage in exclusionary conduct. Innovation can be delayed or suppressed..$^{9}$

The protection of entrepreneurial choice should not be a ticket for favored treatment of small firms. What should be protected is a right to compete on the merits, unhindered by exclusionary or abusive conduct by large firms and as free as possible of government regulation that discriminates against the small provider.

7. See Nat'l Soc'y of Prof'l Eng'rs v. United States, 435 U.S. 679, 695 (1978) (“[T]he assumption that competition is the best method of allocating resources in a free market recognizes that all elements of a bargain - quality, service, safety, and durability - and not just the immediate cost, are favorably affected by the free opportunity to select among alternative offers.") (emphasis added). See also FTC v. Ind. Fed'n of Dentists, 476 U.S. 447, 459 (1986) ("[A]n agreement limiting consumer choice by impeding the 'ordinary give and take of the market place,' . . . cannot be sustained under the Rule of Reason.") (quoting Nat'l Soc'y of Prof'l Eng'rs, 435 U.S. at 692); United States v. Cont'l Can Co., 378 U.S. 441, 453-56 (1964) (discussing the role played by price differences and buyer preferences in influencing consumer choice and creating competition).

8. Robert H. Lande, Consumer Choice as the Ultimate Goal of Antitrust, $62 \mathrm{U}$. PitT. L. Rev. 503, 504-05 (2001); John B. Kirkwood \& Robert H. Lande, The Fundamental Goal of Antitrust: Protecting Consumers, Not Increasing Efficiency, 84 Notre Dame L. Rev. 191, 192 (2008).

9. See Berkey Photo, Inc. v. Eastman Kodak Co., 603 F.2d 263, 301-03 (2d Cir. 1979), cert. denied, 444 U.S. 1093 (1980) (addressing conspiracy to delay introduction of a new electronic flash device developed by General Electric); Mitchell, supra note 1, at 508 (canvassing evidence that small businesses are superior innovators). 
Properly viewed, the connection between competition law and government regulation is straightforward. If competition law is effective in preserving competition, the need for government regulation should be minimized. ${ }^{10}$ Where regulation is needed - as it may be for health and safety reasons - the regulation ought to show the same sensitivity for survival of small firms that antitrust policy should show. Regulations that are designed for, and sometimes at the behest of, large firms can and often do undermine entry, competition, and entrepreneurial choice.

\section{When Small Can Be Superior to Big}

Today, Americans are accustomed to big corporations that provide sophisticated or high-tech products our predecessors could only imagine. Airplanes, automobiles, sophisticated drugs, computers, and other digital products are examples. Many every-day consumables, including processed food, cigarettes, toothpaste, and laundry detergent are the products of very large firms. Critical sectors of retailing are now dominated by large chains.

Despite the prominence of large firms and downturns in the number of newly created and surviving small businesses, ${ }^{11}$ a great deal of what is bought and sold in the marketplace continues to flow through individuals or relatively small businesses. That was true in 1890 and remains true today. According to Census data, 78.5 percent of all firms with paid employees had fewer than ten employees. ${ }^{12}$ The largest number of employer firms operate in professional, scientific and technical services, retail trade, construction, and health care and social assistance. ${ }^{13}$ Small firms and atomistic providers still have a major presence in most service professions, in providing food and drink, in the arts, and in other creative professions. For example, there is high concentration among firms that provide auditing services for large business entities, but there remain hundreds of smaller or solo-practicing

10. See, e.g., Scherer \& Ross, supra note 4, at 18 ("The resource allocation and income distribution problem is solved through the . . forces on the market, and not through the conscious exercise of power held in government hands (that is, under state enterprise or government regulation).").

11. Mitchell, supra note 1, at 502 (citing evidence of the decline in numbers and market share of small businesses in manufacturing and retailing).

12. Nearly 1 in 10 Businesses with Employees Are New, According to Inaugural Annual Survey of Entrepreneurs, Commerce.Gov (Sept. 1, 2016, 12:08 PM), https://www.commerce.gov/news/blog/2016/09/nearly-1-10-businessesemployees-are-new-according-inaugural-annual-survey [https://perma.cc/4 V6P-JGNC].

13. Id. 
accountants that ply their trade for small firms or individuals. ${ }^{14}$ In the healthcare industry, HMOs and large group practices are increasingly common, but solo and small-practice physicians remain very much in demand. And, while we shop for consumables at giant supermarket chains or big box retailers, Americans have not lost interest in buying from local farmers' markets, in drinking the products of local or regional craft brewers or winemakers, or in dining at locally owned eateries. Consumer dissatisfaction is often high when we are forced to deal with large service providers, particularly when choice is limited as with large cable television and telecom providers.

There are obvious issues involving small businesses. Many are short lived. According to a 2016 Census release, over 481,000 firms with paid employees, or 8.9 percent of the total, had been in business for less than two years while only 3.1 percent of firms have been in business for sixteen or more years. ${ }^{15}$ Many small firms struggle on subsistence earnings. Two percent of employer firms had annual receipts of less than $\$ 10,000$; only 25.8 percent of employer firms had receipts of $\$ 1$ million or more. ${ }^{16}$ Small businesses also probably make up a large share of businesses involved in deceptive or fraudulent conduct, or operating outside the regulatory framework.

Despite these issues, small business remains resilient and, in many sectors, the preferred way of doing business. Small enterprises thrive in industries that typically fit in one or more of the following categories: (1) owner-operated businesses that can operate efficiently on a small scale; (2) professionals or other service providers; (3) artists, writers, or athletes whose success is determined by individual initiative and creativity; and (4) producers who sell customized products or who otherwise require a high degree of personal contact with customers or suppliers.

There are obvious explanations for why many industries have remained fertile ground for small business. The first is that these industries may operate more efficiently, flexibly, innovatively, and responsively to local demand when left in the hands of individuals or small firms. The second is that, regardless of economic advantage, both the providers and the customers may prefer the personal contact characteristic of small business.

14. Jessica Fritz, Who Audits Public Companies - 2016 Edition, AuditAnalytics (June 7, 2016), http://www.auditanalytics.com/blog/who-audits-publiccompanies-2016-edition/ [https://perma.cc/LH9W-KUM6] (noting that for smaller companies publicly reporting, none of the Big Four accounting firms have a substantial market share).

15. Nearly 1 in 10 Businesses with Employees Are New, According to Inaugural Annual Survey of Entrepreneurs, supra note 12.

16. Id. 


\section{A. The Efficiencies of Small Businesses}

A primary efficiency harnessed by a franchise system is the individual franchisee's entrepreneurial energy - a quality that may be lacking when individual retail outlets are owned by a large firm. ${ }^{17}$ Salaried store managers may lack the same incentive to work the extra hours that a franchise owner possesses. ${ }^{18}$ The franchise owner may also have substantial authority and flexibility to address day-to-day problems in the outlet's operation.

What is true for franchising will hold with greater force for an owner-operated small business. As compared to a franchisee, the owneroperator has more flexibility to change inventory, location, selling methods, hours of operation, etc. The owner-operator also avoids the incentive for disloyal agency that can be a problem when a firm gives responsibility for purchasing to managers. Using the firm's money to purchase services or inventory, there is a risk that the manager, in breach of her fiduciary duty, will favor a non-competitive supplier because of an under-the-table payment, a family tie, or other personal relationships. ${ }^{19}$ An owner-operator can enter into disadvantageous commercial relationships only at her own cost.

Big businesses can have economies of scale and scope that small firms lack. A large producer can streamline production and marketing in ways that a smaller rival cannot. For many types of manufacturing, processing, and distribution, the advantages of scale can be substantial. ${ }^{20}$ In addition, economies of scope are enjoyed by multi-product firms such as Proctor \& Gamble. Its diverse offerings of consumer products give it a deep pool of resources, an ability to jointly promote and distribute multiple products, and insulation against failure if one

17. See Paul H. Rubin, The Theory of the Firm and the Structure of the Franchise Contract, 21 J. L. \& ECON. 223, 226-29 (1978) (discussing how incentives promote franchisee efficiency). See also Benjamin Klein \& Lester F. Saft, The Law and Economics of Franchise Tying Contracts, 28 J. L. \& ECON. 345, 350 n. 20 (1985) ("[T]he incentive for workers to supply effort that is not explicitly specified and measurable by the employer . . . is harvested by franchising managements.").

18. Large firms that hire local managers can lessen but not eliminate this incentive problem by paying the manager a percentage of profits generated by the managed outlet.

19. See, e.g., Rash v. J.V. Intermediate, Ltd., 498 F. 3d 1201, 1210 (10th Cir. 2007) (finding local manager of national enterprise breached his fiduciary duty by favoring his own scaffolding firm over that owned by the enterprise).

20. Achieving scale efficiencies may require large firms, but often not to the point of dominance or oligopoly. See Joe S. Bain, Advantages of the Large Firm: Production, Distribution, and Sales Promotion, 20 J. Marketing 336, 34546 (1956) (finding that in many industries achieving minimum efficient scale did not require a highly concentrated industry structure). 
of its lines should flounder. Not all efficiency advantages, however, favor the large firm.

A prominent business theorist wrote that large companies "make fewer but bigger errors, tend to continue wrong policies too long, and have the resources to delay until crisis is unmistakable." ${ }^{21}$ Another observed that "[a] big organization is bureaucratic, harder to inspire and energize, and much less likely to respond to the energies of a few creative people." ${ }^{22}$ As a firm becomes larger, its bureaucratic structure makes it more difficult to trace costs and benefits of creative conduct within the organization. ${ }^{23}$ There is strong anecdotal evidence to support the view that large firms are more subject to the momentum of the status quo and less willing to experiment and innovate. A petroleum industry expert, focusing on the waste and pollution caused when methane or natural gas is burned at a drilling source rather than captured and distributed, suggested that innovation addressing this problem is likely to come from small firms, not giant firms that tend to be cautious about change. ${ }^{24}$ The giant Bell Corporation, a dominant firm in offering telephone service throughout most of the twentieth century, did not introduce automatic switching machines until well after a number of

21. Corporate Takeovers (Part I): Hearings Before the Subcomm. on Telecomms., Consumer Prot. and Fin. of the H. Comm. on Energy and Commerce, 99th Cong., 1st Sess. 259 (1985) (testimony of Warren A. Law, Edmund Cogswell Converse Professor of Finance, Harvard Business School). Professor Law continued: "Corporate history is replete with examples. In the absence of compelling technical advantages of large size, there is ground to prefer small productive units to large." Id.

22. Alonzo L. McDonald, Of Floating Factories and Mating Dinosaurs, 64 HARv. Bus. REv. 82, 83 (1986).

23. M. S. Moyer, The Roots of Large Scale Retailing, J. Marketing, Oct. 1962, at 55, 57 ("In the large organization, responsibility for the attainment of profit objectives must be apportioned and reapportioned many times. . . . Costs tend to become nontraceable.").

24. Oil Innovators See Opportunity Amid Record Low Prices, PBS Newshour (Aug. 25, 2015, 6:20 PM), http://www.pbs.org/newshour/bb/oil-innovatorssee-opportunity-amid-record-low-prices [https://perma.cc/2WDH-7ZLJ]. The segment described the wasted natural gas that escapes during drilling, typically polluting when burned at the site, and quoted industry expert Carl Larry:

We need a Steve Jobs in oil and gas. We need somebody who is going to go out there and take a chance. Big companies aren't. They're just going to keep their budgets going doing what they do right now and making money. But the ones who take the chances are the small businesses, the people who have the guts to take it out and try something new.

Id. 
smaller telephone companies had adopted this innovation..$^{25}$ Recent empirical evidence supports anecdotal accounts that small firms are often a superior engine for innovation. ${ }^{26}$

Those economies that favor large size are, in any event, likely far more limited in the service professions, in businesses that involve extensive service for the customer, or creative component industries. In any industry in which there is a strong service component, economies of scale are achieved at lower size levels and there is heightened need for close and nurtured relationships between buyer and seller. ${ }^{27}$ One management expert estimates that the optimum size of a professional service organization "is probably between 35 and 100 people." ${ }^{28}$ Not only do economies of scale end as firm size increases-large agglomerations of service providers are likely to incur diseconomies. ${ }^{29}$ One example is a large law firm. The firm's size has some advantages, such as its ability to refer clients to specialists within the firm. But there are large firm inefficiencies, such as added supervisory costs, resolving profit and benefit allocations among participants, and resolving potential conflicts of interest among its many clients. ${ }^{30}$

The banking industry provides an example of the relevance of size in a service-oriented industry. Large banks have the resources and expertise to make substantial loans to multinational businesses, sometimes by forming consortia involving other large lending institutions. A community bank would not be suited to this task. However, when it comes to the banking services that a small business or a

25. Sheldon Hochheiser, Electromechanical Telephone-Switching, ENGINEERING \& TECH. Hist. WikI, http://ethw.org/Electromechanical_Telephone-Switching [https://perma.cc/ZRC8-CMF2] (last updated Jan. 9, 2015, 5:22 PM) (stating that AT\&T Bell had automatic switching technology as early as 1903, but resisted adopting the systems).

26. See Mitchell, supra note 1, at 508 (citing Wilfred Dolfsma \& Gerben van der Velde, Industry Innovativeness, Firm Size, and Entrepreneurship: Schumpeter Mark III?, 24 J. Evolutionary ECON. 713, 728 (2014)) (noting research finding that industries populated with small businesses generate new products and services at a faster rate than oligopoly dominated industries).

27. See Michael D. Johnson \& Fred Selnes, Customer Portfolio Management: Toward a Dynamic Theory of Exchange Relationships, J. Marketing, Apr. 2004 , at 1, 15 ("[T] he more a firm is positioned toward product offerings with low economies of scale (i.e., high personal-service component), the stronger it must be in developing and keeping closer relationships.").

28. McDonald, supra note 22, at 83 ("When you have more than 100 professionals under one roof, extra layers of supervision are common, indeed inescapable, and the organization becomes overregimented.").

29. Id.

30. See $i d$. ("Each layer [of supervision] adds expense, but not necessarily benefit to the client."). 
consumer needs, community banks perform very well, often better than their larger rivals. ${ }^{31}$ A prominent former IMF economist estimated that the most efficient size of a bank is under $\$ 10$ billion in assets. ${ }^{32}$ Perhaps because of fewer levels of bureaucratic overlay, small banks - when compared to their largest competitors-provide banking services at lower charges, lend more to small businesses, and have lower default rates. ${ }^{33}$ These findings are hardly surprising. Banking is a serviceintensive industry where personal relationships matter and where knowledge of local conditions can be critical. As with other service oriented industries examined here, maintaining the rules of competition so that small banks may enter and survive serves both efficiency and quality of life goals.

\section{B. Creativity}

The notion that a Beethoven Symphony could not have been written by committee is relevant in many areas of the creative arts. Successful writers may have contracts with publishers. Producers, directors, and screen writers in entertainment are often employed by the major studios. But a beautiful painting, a soaring musical work, and a good book are typically the work of a single individual, who then may sell it to a firm for production or publication. Lennon and McCartney, while collaborating on memorable tracks, did not take orders from a corporate superior. Screen plays may be collaborations, some of them under a large corporate umbrella. Still, creation of film and video programs remains a creative occupation with many individuals and small firms pressing to offer new content. ${ }^{34}$

Individual efforts are also at the core of those who present and entertain, including actors, musicians, and athletes. Creative individuals could well be stifled or repressed if they are subject to the regimen of a large firm. The inherent advantages of individual performance in the creative world is demonstrated when, even among nations that have experimented with centrally planned economies, creators and performers have maintained a high degree of independence.

31. See Mitchell, supra note 1, at 505-06 (noting that community banks charge lower fees, have lower default rates on loans, and lend a greater proportion of money to small businesses).

32. Implications of the "Volcker Rules" for Financial Stability: Hearing Before the S. Comm. on Banking, Hous., and Urban Affairs, 111th Cong. 47 (2010) (statement of Simon Johnson, Ronald A. Kurtz Professor of Entrepreneurship, Sloan School of Management, Massachusetts Institute of Technology).

33. Mitchell, supra note 1 , at 505-06.

34. The number of independent artists, writers, and performers is estimated to be over 765,000. Roland J. Kushner \& Randy Cohen, National Arts Index 2016: An Annual Measure of the Vitality of Arts and Culture in the United States: 2002-2013 39 (2016). 


\section{Lifestyle Preferences for Entrepreneurial Independence}

Another reason for the resilience of small or individually owned firms is that both the suppliers and customers prefer to do business this way. Simply put, for most people, "the smaller the work unit, the greater the satisfaction." 35 Efficient or not, many service providers, small retailers, farmers, and fishermen want to own and manage their own business. Collectively, small retailers offer a rich variety of choices that consumers continue to patronize - the best indication that this distribution method is attractive to both buyers and sellers. Most small restaurants are not highly profitable and may struggle to survive. They are nonetheless able to maintain a loyal customer base, capture entrepreneurial incentives from the owner, and become a vital part of the local economy. People in the creative arts often work for the love of their craft. J.K. Rowling notwithstanding, many writers and actors struggle to survive in a line of work about which they are passionate. ${ }^{36}$

This preference for independence can of course be linked to efficiencies. An owner who is sweeping the floor of a small retail business may do so more willingly and with more enthusiasm than an employee would. There is, however, value in the non-efficiency related level of satisfaction that the owner manager enjoys. To ignore this value is to move antitrust policy toward an impersonal and Orwellian world difficult to reconcile with Sherman Act values.

\section{Antitrust and Regulatory Failures in Three Critical Industries}

The lives of both consumers and industry participants are adversely affected when antitrust and regulatory policy do not adequately protect entrepreneurial choice. Antitrust failures include tepid merger enforcement that has allowed large buyers to merge to tight oligopsony. When these oligopsonists employ exclusionary purchasing tactics that harm individual or small-firm sellers, orthodox antitrust policy and Supreme Court procedural decisions have often denied small sellers an antitrust remedy. Finally, when vulnerable individuals or small firms engage in collective action to counter oligopsony power, they can themselves become targets of antitrust enforcement directed at collective action. Three critical industries examined below illustrate these points.

35. McDonald, supra note 22 , at 83.

36. See Kushner \& Kohen, supra note 34, at 39 ("Many independent artists ply their cultural trade on a part-time basis, combining arts entrepreneurship with other jobs and work."). 


\section{A. Agriculture}

In 1890, and for at least the three decades that followed, agriculture and the Sherman Act were joined at the hip. Rural Americans were a key constituency pressing for antitrust legislation-support that was illustrated by the frequent references to agriculture in congressional debates. ${ }^{37}$ Key targets were processors and the rail industry that transported goods to processors. ${ }^{38}$ What followed were key enforcement initiatives directed at railroads ${ }^{39}$ meat packing, ${ }^{40}$ tobacco, ${ }^{41}$ and oil. ${ }^{42}$ The Packers and Stockyards Act of 1921 further buttressed the enforcement framework intended to protect competition considered vital for farmers and ranchers. ${ }^{43}$

By the mid-twentieth century, agriculture was no longer the focus of antitrust enforcement. Even private enforcement actions that might have aided small farmers fell on hard times $^{44}$ as the Supreme Court stiffened procedural and substantive requirements. In Cargill, Inc. v. Monfort of Colorado, Inc. ${ }^{45}$ the Court did not address buyer-power issues and followed simplistic Chicago School logic in reversing a lower court decision that would have thwarted further consolidation of the beef packing industry. ${ }^{46}$

Levels of concentration tolerated in seller-power industries are anathema when the same firms exercise buyer power over vulnerable, atomistic sellers. Plant and animal products that spoil or become less

37. 21 Cong. ReC. 2,470-71 (1890) (statement of Sen. Allison) (citing concerns from his farmer constituents about trusts in Chicago suppressing the price of cattle); see also Hans B. Thorelli, The Federal Antitrust Policy: Origination OF AN AMERICAN TRADITION 143 (1955) (discussing farm organizations' political involvement).

38. ThORELLI, supra note 37 , at 58-60.

39. N. Secs. Co. v. United States, 193 U.S. 197 (1904).

40. Swift \& Co. v. United States, 196 U.S. 375 (1905).

41. United States v. Am. Tobacco Co., 221 U.S. 106 (1911).

42. Standard Oil Co. of N.J. v. United States, 221 U.S. 1 (1910). Standard Oil was accused in part of facilitating railroad cartels. Id. at 32-33.

43. Packers and Stockyards Act of 1921, Pub. L. No. 67-51, 42 Stat. 159 (codified as amended at 7 U.S.C. $\S \S 181-229$ (2012)).

44. Private plaintiffs had a notable mid-twentieth century success in Mandeville Island Farms, Inc. v. Am. Crystal Sugar Co., 334 U.S. 219 (1948) (forbidding sugar refiners' conspiracy to suppress the price paid for sugar beets).

45. 479 U.S. 104 (1986).

46. Id. at 119. See Jon Lauck, Toward an Agrarian Antitrust: A New Direction for Agricultural Law, 75 N.D. L. REV. 449, 503-04 (1999) (criticizing Cargill and other merger cases that failed to address supplier issues and noting that buyerpower issues were not squarely addressed in the Cargill briefs). 
valuable after a prime selling time increase the vulnerability of a small seller to a powerful buyer. ${ }^{47}$ Geographic limits on buyer markets are a critical issue for farmers and ranchers. That meat processing plants may be relatively unconcentrated in national terms is irrelevant to a rancher who must find a buyer quickly and, because of substantial transportation costs, in a relatively limited geographic area. The farmer's vulnerability to powerful buyers is borne out by a model that showed prices received by a hog farmer dropped in direct correlation to the degree of concentration among meat packers. ${ }^{48}$ Today, meat processing is highly concentrated nationally, and even more so when one considers the limited geographic market available for those selling livestock. ${ }^{49}$

Choice of product is also an issue. Many consumers prefer to eat beef from cattle raised on a natural grass-fed diet. ${ }^{50}$ The market, however, can be distorted by the power of oligopolistic processors. In the United States, industrial ranching practices call for cattle, around one year of age, to be removed from pastures where they consumed a biologically suited grass diet. ${ }^{51}$ They are then stacked into two story trucks and transported for up to twenty hours with no food or drink to crowded feedlots that contain up to 18,000 cattle. ${ }^{52}$ From this point on, the animals can no longer graze, but are fed diets consisting of corn and soybeans, sometimes supplemented with candy to increase animal weight, the slaughterhouse remains of chickens, pigs, or other cows, plastic pellets to add the fiber that would be in the natural grass diet, and even waste material taken from a chicken coop consisting of chicken feed and manure. The animals can also be dosed with hormones and

47. Roger D. Blair \& Jeffrey L. Harrison, Antitrust Policy and Monopsony, 76 Cornell L. Rev. 297, 313 (1991) (explaining the vulnerability of a seller of a perishable product); Grimes, supra note 6, at 567-68 (same). See also Todd v. Exxon Corp., 275 F.3d 191, 211 (2d Cir. 2001) (making the related point that "[1]abor is an extremely perishable commodity - an hour not worked today can never be recovered" (citation omitted)).

48. Philip Paarlberg et al., Structural Change and Market Performance in Agriculture: Critical Issues and Concerns About Concentration in the Pork Industry 6-7 (Dep't Agric. Econ. Purdue Univ., Staff Paper No. 14, 1999) (a marketplace with twenty equally sized pork packers would pay about 5 percent less than a perfectly competitive marketplace; eight firms would pay 18 percent less; and four firms would pay 28 percent less).

49. For example, 80 percent of the beef purchased in the U.S. is sold by the four largest processors. Andrea Rock, How Safe Is Your Beef?, Consumer ReP., Oct. 2015, at 26, 32 .

50. Georgina Gustin, Demand for Grass-Fed Beef is Growing, L.A. Times (Nov. 23, 2012), http://articles.latimes.com/2012/nov/23/business/la-fi-grassfed-beef20121123 [https://perma.cc/4RGG-XDEX].

51. Rock, supra note 49 , at 27 .

52. Id. at 31. 
antibiotics to prevent disease and promote growth. ${ }^{53}$ In feed lots, they stand in areas of as little as twenty-three square feet per animal, the equivalent of a four-foot by six-foot enclosure, with no vegetation, a great deal of manure, and often lots of mud. ${ }^{54}$ Life in a feeding station can be from three months to a year before they are taken to a slaughterhouse. ${ }^{55}$

These industrial practices are, in a narrow sense, efficient, and at least some of these savings may be passed on to consumers in the form of lower prices. Cattle raised in accord with industrial practices can be brought to slaughter weight as much as a year more quickly than an animal that stays on a natural, grass-fed diet. The beef from a grassfed animal, with no antibiotics added to its diet, can cost up to $\$ 3$ more per pound, a reflection of the longer growth period and greater space requirements for the grass-fed animal. ${ }^{56}$ Using industrial methods, more cattle can be raised with a smaller land and labor footprint, so more beef can be supplied.

The short-sighted industrial efficiency that prevails in beef production also governs in poultry. In the United States, the raising of chickens still is a hands-on job done by hundreds of small entrepreneurs who contract with a handful of very large chicken processors and distributors. Many find they are indebted to the processors for the costs of their equipment, are forced to upgrade their facilities at substantial cost, and - short of bankruptcy - must continue to struggle under oppresssive conditions for themselves and their livestock. ${ }^{57}$ These conditions led one economist to compare the chicken farmer's plight to economic serfdom. ${ }^{58}$ At the other end of the chain, factorycommoditized chicken is available in supermarkets at relatively low prices, but consumer choice and quality is limited.

The efficiencies of raising animals in crowded industrial conditions are open to question. There is evidence that free range chickens that can eat bugs, grubs, and worms as part of a natural diet produce smaller but more nutritious eggs, and that their eggs have thicker shells less

\footnotetext{
53. Id. at $30-31$.

54. Id. at 27 .

55. Id. at 30 .

56. Id. at 32 .

57. C. Robert Taylor, ALFA Eminent Scholar Agric. \& Pub. Policy, Auburn Univ., Comments presented at the Department of Justice \& Federal Trade Commission Joint Workshop on Merger Enforcement 248-49 (Feb. 17, 2004) (transcript available at https://www.ftc.gov/news-events/events-calendar/2004/ 02/ftcdoj-joint-workshop-merger-enforcement [https://perma.cc/ZRV8-Q53P]).

58. $I d$. at 216 .
} 
prone to breakage. ${ }^{59}$ The workers who work with free-range chickens reportedly have fewer respiratory health issues than those who work in crowded chicken coops. ${ }^{60}$ Many of the additional costs to industrial farming are external costs that are passed on to society, among them the degradation of antibiotics that are fed to animals and ingested in small doses each time a consumer eats the meat. ${ }^{61}$ Other external costs are the environmental burden on society from the fecal dust and unwelcome odors emanating from feed lots, the burden of disposing of large amounts of concentrated animal waste, and even the social welfare benefits that must be paid to some of the contract farmers or their employees because of poverty level income. ${ }^{62}$

Some farmers have refused to follow industrial farming practices and raise animals following centuries old animal husbandry practices. They have an opportunity for success as fast food chains and supermarkets begin to offer alternatives to meat produced through industrial farming practices. The story, however, does not end here.

The labels "organic," "natural," or "free range" have to some degree been coopted by large meat processors, who still find ways of short cutting traditional animal husbandry practices and selling their products with such labels. Chickens stuffed into crowded hen houses are given a small outside area to escape, then are sold as "free range." 63 They are advertised as having no "antibiotics" added to their food, but cannot eat the natural diet of grubs, bugs, and worms that would produce eggs with thicker shells and the dark yellow yolks of a

59. Daphne Miller, Farmacology, What Innovative Family Farming Can Teach Us About Health and Healing 106-10 (2013).

60. Id. at $119-20$.

61. A Consumer Reports Study found that while bacteria are found in beef regardless of how the cattle are raised, there was a notable increase in certain types of bacteria, including those resistant to antibiotics, in beef from cattle sent to feedlots. Rock, supra note 49, at 29.

62. James M. MacDonald \& Penni Korb, U.S. Dep't Agric. Econ. Res. Serv., Econ. Info. Bull. No. 72, Agricultural Contracting UPDATE: Contracts in 2008 (Feb. 2011) at 1, 20 (finding that the mean household income from broiler-only operations amounted to $\$ 14,890$ in 2008). Low-paying jobs of all sorts can result in society bearing external costs in the form of social-welfare benefits. For example, low-paid Wal-Mart workers have reportedly received state or federal welfare benefits. Abigail Goldman, Study Cites Social Costs of Wal-Mart, L.A. Times (Aug. 3, 2004), http://articles. latimes.com/2004/aug/03/business/fi-walmart3 [https://perma.cc/9MJH-PPKZ] (describing three surveys detailing state or federal assistance received by Wal-Mart employees).

63. Michael Pollan, The Omnivore's Dilemma: A Natural History of Four Meals 169-73 (2006) (describing a tour of a large chicken-raising facility that markets eggs as organic and free range). 
traditional free range chicken. These eggs might more accurately be labeled "industrial organic." ${ }^{4}$

These practices border on deceptive. Leaving aside any consumerprotection issue, industrial organic farming makes it more difficult for a farmer and processor desiring to use traditional husbandry practices. Retailers that might otherwise be persuaded to carry the farmer's genuinely organic animal products will be pressured to carry instead the mass-produced industrial "organics." These woes are compounded by federal regulation, which is designed to fit the industrial processor's practices. For example, dominant chicken processors slaughter poultry in a large industrial facility that must meet USDA requirements for impermeable, white washed walls and antiseptic conditions. ${ }^{65}$ It is difficult for a small chicken farmer raising chickens under more natural conditions to satisfy these requirements. The regulations do not require measuring the actual bacterial content of the slaughtered animals, which would seem the most relevant test. ${ }^{66} \mathrm{~A}$ small-volume organic processor may choose to slaughter the animals in a natural outdoor facility, which many believe results in the lowest bacteria exposure. That processor, however, may be out of compliance because it has no walls to white wash and treat with antiseptic chemicals. ${ }^{67}$ The genuine organic farmer or processor risks closure or operation as a rogue facility. ${ }^{68}$

These regulatory obstacles are outside the reach of antitrust authorities. At the same time, timid merger enforcement was complicit in creating the oligopolistic conditions that surround USDA regulation. Regulators of meat products respond to the industry, but presumably do not seek to change its structure or the power distribution within that industry. Consider how food regulation might differ if a large percentage of meat products - say 20 percent or more-were raised, slaughtered, and brought to market in accord with more traditional animal husbandry practices. A less concentrated processing industry would likely respond more flexibly to consumer demand, offering more choices. USDA regulation that is now designed for large plant meat

64. Id.

65. Id. at $228-29$.

66. Id. at 229 .

67. Id. at 228-30 (describing the difficulties that a small, organic processor of chickens confronts in complying with USDA regulations).

68. Some pioneers in organic and naturally raised animals have tried to thread the regulatory and oligopoly obstacles by establishing direct, farm to table options. For example, a direct ranch to table distribution system for grass-fed beef was established by Colorado rancher Mike Callicrate. Protocol, Callicrate Cattle Co., http://www.callicratecattleco.com/Protocol.htm [https://perma. cc/P3LX-CKQ4] (last visited Sept. 14, 2017). 
processing would be forced to adjust to consumer demand for organic farming practices.

The Justice Department, in its 2012 report on competition in agriculture, acknowledged special monopsony issues in agriculture mergers. ${ }^{69}$ That report, however, stopped well short of recognizing the unique vulnerability of the small producer to monopsony power and the need for more stringent controls of mergers that increase buying power. The Cargill case is a classic case of neglect of the buyer-power issue. ${ }^{70}$ Seen only from a short-term consumer price perspective, further concentration of beef packers may have seemed benign. From the perspective of cattle ranchers or consumers wishing more choice in how cattle are raised and slaughtered, the picture is starkly altered. The merging firms could, by reducing a rancher's alternatives, place downward pressure on prices paid for cattle. If only a portion of the reduced costs were passed on to consumers, the oligopolistic beef packers could expect higher margins and profits.

The Justice Department Report also failed to recognize the difficulties faced by affected producers who might seek antitrust relief. Most contract farmers, for example, are afraid to act publicly to question the actions of the processor on whom they depend. The class action enforcement vehicle is becoming less viable as the Supreme Court has made rulings that limit the availability of class action relief. The Court's decision in American Express Co. v. Italian Colors Restaurant ${ }^{71}$ invites processors to insert no-class-action clauses in their contracts with farmers to prevent both arbitration and litigation on a class action basis. ${ }^{72}$ Changes in substantive law add to these difficulties. The Supreme Court's decision in Weyerhaeuser Co. v. Ross Simons Hardwood Lumber Co., Inc. ${ }^{73}$ created a heavy burden on any atomistic seller alleging predatory buying practices. ${ }^{74}$ These changes in the law governing private enforcement of the Sherman Act place increased importance on prophylactic merger enforcement that could lessen the occurrence of power abuses in agriculture. The question remains

69. U.S. Dep't of Justice, Competition and Agriculture: Voices from The Workshops on Agriculture and Antitrust Enforcement in Our 21st Century Economy and Thoughts on the Way Forward 18-19, 21 (2012), https://www.justice.gov/sites/default/files/atr/legacy/2012/ 05/16/283291.pdf [https://perma.cc/9VTQ-SBU9].

70. See supra note 46 and accompanying text.

71. 133 S. Ct. 2304 (2013).

72. Id. at $2309-12$.

73. 549 U.S. 312 (2007).

74. Id. at $318-20$. 
whether invigorated enforcement, assuming it were to occur, would be too late to preserve or restore a competitive market structure.

\section{B. Healthcare}

The United States has by far the most expensive healthcare in the world. ${ }^{75}$ Even after implementation of the Affordable Care Act, the system fails to provide healthcare for all of its citizens. ${ }^{76}$ Measures of health outcomes also suggest that the United States lags behind most developed nations. Based on data from the Organisation for Economic Co-Operation and Development in 2010 - gathered before the Affordable Care Act was enacted - the United States had by far the highest per capita spending on healthcare, drug prices, and cost per hospital visit of the twelve developed nations gathered. Yet the United States performed near the middle on case-specific hospital mortality and poorly on hospital admissions for chronic conditions and amputations due to diabetes. ${ }^{77}$ Another study showed that, despite vastly higher per capita expenditures on healthcare, the United States ranked last, by a wide margin, among thirteen developed nations in averting preventable deaths - deaths from preventable diseases or complications. ${ }^{78}$

75. U.S. expenditure and financing of healthcare represented 17.2 percent of gross domestic product in 2016, whereas Switzerland - the second highest-was 12.4 percent. Health Expenditure and Financing, Org. FOR ECON. Co-Operation \& Dev. http://stats.oecd.org/index.aspx?DataSetCode=SHA [https://perma. cc/5ESE-C87U].

76. In 2015, 9.1 percent of the US population had no health insurance for any portion of the year. U.S. Census Bureau, P60-257 (RV), Health Insurance Coverage IN THE United States: 20153 (2016), https:/ /www.census.gov/library/publications/2016/demo/p60-257.html [https://perma. cc/W9Y3-A2Z3].

77. David A. Squires, The U.S. Health System in Perspective: A Comparison of Twelve Industrialized Nations, COMmonweAlth Fund: Issues INT'L Health PoL'Y, July 2011, at 1, 2. The same source reports that the U.S. performed very well for survival rates in cervical, breast, and colorectal cancer. Other variables affect these comparative statistics. For example, U.S. dietary habits are likely to have contributed to the poor results for diabetes-related ailments. On the other hand, wider health insurance coverage could have improved diabetes outcomes by providing patients with better information and preventive care. Id. New Zealand, which had the lowest healthcare expenditures among the twelve nations - barely more than a third of US per capita expenditures - had similar or superior outcomes for most measures of healthcare quality. Id. Compared to the U.S., New Zealand had similar five-year survival rates for cervical cancer but slightly lower survival rates for breast and colorectal cancer. $I d$. at 10 .

78. Melissa Etehad \& Kyle Kim, The U.S. Spends More on Healthcare Than Any Other Country -But Not With Better Health Outcomes, L.A. Times (July 18, 2017, 4:25 PM), http://www.latimes.com/nation/la-na-healthcare-comparison20170715-htmlstory.html [https://perma.cc/7FHL-47WA] (citing a study of the European 
At the start of the U.S. healthcare supply chain are many atomistic doctors, therapists, and medical professionals. At the other end are consumers. In the middle, however, are some highly concentrated oligopolies playing key roles, including hospitals, health insurers, drug manufacturers, retail pharmacies, and prescription benefit managers. Further complications are presented by the patent system covering new drugs - a system of health insurance that dulls patient incentives to bargain for quality care at the best price - the difficulty consumers have in rating the quality of medical service and treatments, and the complex regulatory overlay.

Although the enforcement agencies have been proactive in recent years in challenging mergers that would result in further consolidation by hospitals, insurers, prescription management firms, and pharmaceutical manufacturers, ${ }^{79}$ their efforts may be too little too late. ${ }^{80}$ In some instances, well-grounded challenges to mergers have met resistance in the courts. ${ }^{81}$ In other instances, the agencies failed to challenge

Observatory on Health Systems and Policy). The study showed that for 2013, the U.S. had 112 preventable deaths per 100,000. Among the other twelve developed nations, the preventable deaths ranged from fifty-five to eighty-five. Id.

79. FTC \& U.S. Dep't of Justice, Hart-Scott-Rodino Annual Report: Fiscal Year 2015, at 1, 15-18, 20-22, https://www.ftc.gov/system/files/documents/reports/federaltrade-commission-bureau-competition-department-justice-antitrust-division-hartscott-rodino/160801hsrreport.pdf [https://perma.cc/CB4S-DJNB] (showing that of the twenty-two FTC merger challenges, eleven involved healthcare industry mergers). In 2017, the Justice Department was successful in blocking two major health insurance mergers: Anthem's attempt to combine with Cigna, Press Release, U.S. Dep't of Justice, D.C. Circuit Affirms Decision Blocking Anthem's Acquisition of Cigna (Apr. 28, 2017), https://www.justice.gov/opa/pr/dccircuit-affirms-decision-blocking-anthem-s-acquisition-cigna [https://perma.cc/ GL69-DTTJ], and Aetna's attempt to combine with Humana, United States v. Aetna Inc., 240 F. Supp. 3d 1 (D.D.C. 2017).

80. A number of critics conclude that high hospital prices are linked to lessened competition in local hospital markets. Zack Cooper et al., The Price Ain't Right? Hospital Prices and Health Spending on the Privately Insured 34 (December 2015) (unpublished manuscript) (on file with the Case Western Reserve Law Review); Leemore Dafny et al., The Price Effects of Cross-Market Hospital Mergers 29 (Nat'l Bureau of Econ. Research, Working Paper No. 22106, 2017); Tim Xu et al., The Potential Hazards of Hospital Consolidation: Implications for Quality, Access, and Price, 314 J. Am. Med. Ass'N 1337, 1338 (2015).

81. The enforcement failures of the 1990s include FTC v. Tenet Heathcare Corp., 186 F.3d 1045 (8th Cir. 1999); FTC v. Freeman Hosp., 69 F.3d 260 (8th Cir. 1995); United States v. Mercy Health Servs., 902 F. Supp. 968 (N.D. Iowa 1995), vacated as moot, 107 F.3d 632 (8th Cir. 1997); FTC v. Butterworth Health Corp., 946 F. Supp. 1285 (W.D. Mich. 1996), aff'd, 121 F.3d 708 (6th Cir. 1997). More recently, the FTC failed in two district court rulings but succeeded on appeal in obtaining preliminary injunctions halting proposed hospital mergers. FTC v. Penn State Hershey Med. Ctr., 185 F. Supp. 3d 552 (M.D. Pa. 2016), rev'd, 838 F.3d 327 (3d 
mergers that resulted in price increases. In his review of retrospective studies of mergers, John Kwoka concluded that price increases from hospital mergers, along with mergers involving journals and airlines, were likely to involve the highest increases in prices. ${ }^{82}$ Price increases to consumers, however, are likely only one of the anticompetitive effects of concentration in the mid-levels of the distribution chain. Choices and effects on quality of care, although more difficult to quantify, are likely. ${ }^{83}$

There are substantial advantages to being a solo-practicing physician. One can maintain control over treatment of individual patients, avoiding the "turnstile" medicine associated with corporate practice. To maximize revenues, a corporate practice may favor more profitable treatments over equally or more effective ones or it may require a patient to return for separate visits to deal with multiple diagnosed problems. ${ }^{84} \mathrm{~A}$ solo-practicing physician can place patient interest above financial gain and treat all problems in a single visit. Even with this financial sacrifice, at least for some specialists, monetary incentives still favor a doctor's solo practice. One Southern California allergist estimated that a solo-practicing doctor in his line, once the practice was established, could easily earn two or three times more than a salaried colleague in corporate practice. ${ }^{85}$

Despite these substantial advantages to solo practice, most young doctors do not choose this option. ${ }^{86}$ Consider the motivated medical

Cir. 2016); FTC v. Advocate Health Care Network, No. 15 C 11473, 2016 WL 3387163 (N.D. Ill. 2016), rev'd, 841 F.3d 460 (7th Cir. 2016).

82. John E. Kwoka, Mergers, Merger Control, and Remedies: A Retrospective Analysis of U.S. Policy 154-55 (2015).

83. Tim Xu et al., supra note 80 , at $1337-38$.

84. Current Medicare payment practices invite this multiple visit scheme. The author is grateful for information provided by interviews with solo-practicing physicians for this insight. See also Tamara B. Hayford, The Impact of Hospital Mergers on Treatment Intensity and Health Outcomes, 47 Health Servs. RES. 1008, 1026 (2012) (finding that "hospital mergers are associated with greater treatment intensity, both in the type of treatment utilized and in the number of procedures [patients] received during a hospital stay," and "increased utilization of intensive surgeries").

85. The author is grateful to a solo-practicing Southern California allergist for these insights. Notes of the interview are on file with the author.

86. "The share of solo practices" for family physicians "fell to 18 percent in 2008 from 44 percent in 1986." Gardiner Harris, Family Physician Can't Give Away Solo Practice, N.Y. TIMES, (April 22, 2011), http://www.nytimes.com/ 2011/04/23/health/23doctor.html_[https://perma.cc/Y4QC-U5TF]. Despite this downturn, the American Academy of Family Physicians still maintains a link on its website specifically designed to assist the solo practitioner or small group practice. AmERican ACADEMy of Family Physicians, http://www.aafp. 
school graduate who might prefer to start her own practice. Because of large debt coming out of medical school, she is reluctant to incur an even greater debt required to carry her through the cash-strapped startup years. Banks, recognizing the new realities of private practice, may be reluctant to lend a young doctor the needed startup funds. ${ }^{87}$ The lure of an immediate salary from an HMO or corporate practice, despite its relatively modest amount, is substantial. The control exercised by oligopsonistic health insurance companies and large hospitals increases the risks of going the private-practice route. Health insurance companies "own" the patient. If the solo-practicing physician is unwilling to accept the payment rate offered by the insurer, the patient will often switch to a different doctor. Meanwhile, the doctor has no leverage to negotiate with the insurer; 88 the insurer presents the payment package to the doctor on a "take it or leave it" basis. Consumer choice, entry, quality of service, and quality of life all can be adversely affected.

Depending on a doctor's specialty, access to a hospital can be an issue for a solo-practicing physician. The doctor may have some leverage if there is competition among competing hospitals. That leverage quickly dissipates when oligopolistic conditions develop among local hospitals. ${ }^{89}$ To avoid the pitfalls of exclusion or take-it-or-leave-it terms from power-wielding hospitals, the physician is once again pushed away from solo practice and toward a corporate or large group practice.

The point is not that small or solo-practicing physicians always perform better than large group or hospital practices. Indeed, the ranks of small practice doctors include their share of incompetent physicians, or even some who engage in fraud. Some family physicians believe that they can perform better when a group practice lightens their load of patients and gives them better access to peer guidance. ${ }^{90}$ But small practices also include some top performing doctors who prefer to operate independently and who have loyal patients who prefer the small practice setting. Choice should be preserved for both practicing physicians and for their patients.

org/practice-management/administration/central.html [https://perma.cc/526Y3X7X] (last visited Sept. 21, 2017).

87. Harris, supra note 86 (noting that even if young doctors want to start a private practice, "banks - attuned to the growing uncertainties - are far less likely to lend the money needed.").

88. Id. ("[L]arge group practices can negotiate higher fees from insurers . . ..").

89. See, e.g., Jefferson Parish Hosp. Dist. No. 2 v. Hyde, 466 U.S. 2 (1984). Hyde was a solo-practicing anesthesiologist who was excluded from the hospital when the hospital contracted exclusively with a group-practicing firm. Id. at 5 .

90. See Harris, supra note 86 (quoting a family practitioner who left a two-person practice for a government job). 
If the United States is committed to a competitive healthcare economy, eliminating oligopsonistic conditions in industries such as health insurance and hospitals is vital. Unless these concerns are addressed, the young medical school graduate will have strong disincentives to starting her own practice. Her life style preference is thwarted, a loss in and of itself, but one that is directly connected to performance and the quality of the services that she will provide to patients. In Canada, where a single payer system is in effect, a substantially larger percentage of physicians are in solo or small practices ${ }^{91}$ an indication that many doctors prefer this mode of practice when the system does not deter it.

Healthcare antitrust guidelines adopted by the federal antitrust agencies have operated as a perverse incentive for doctors to affiliate. Responding to pressure of large insurance companies and hospitals, doctors have sought, without the protection of the labor laws, to form cooperative groups to negotiate reimbursement rates. The Healthcare Guidelines seek to address this form of cooperative rate negotiation, ${ }^{92}$ but do so by encouraging affiliations and cooperative arrangements thought to make medical practice more efficient. The underlying premise of these regulations is that price fixing, or joint rate negotiation, should be permitted only when there are offsetting efficiencies derived from integration of physician practice. ${ }^{93}$ However well intended, the guidelines operate as a regulatory scheme to encourage integration or consolidation of medical practices and a disincentive to solo-practicing or small practice physicians.

On more than a few occasions, antitrust has thwarted oppressed sellers' collective efforts to protect their interests. Most individual entrepreneurs or small businesses are not protected by labor law exemptions, so collective action as a response to oligopsony power has been attacked as an unlawful antitrust conspiracy. ${ }^{94}$ The case law

91. Compare National Physician Survey, 2004, Nat'L Physician Surv., http:// nationalphysiciansurvey.ca/wpcontent/uploads/2012/10/NPS2004-National-byProv-Binder.pdf [https://perma.cc/SR7G-VB4J] (last visited Sept. 12, 2017) (finding that in Canada in 2004, 32 percent of physicians were in solo practice and 54 percent were in group practice), with Harris, supra note 86 (finding that as of 2008, in the U.S. only 18 percent of family practitioners were in solo practice).

92. Dep't of Justice \& FTC, Statements of Antitrust Enforcement Policy in Health Care 43 (Aug. 1996).

93. Id. at $71-73$.

94. See FTC v. Superior Court Trial Lawyers Ass'n, 493 U.S. 411, 431-32 (1990) (holding that the association of court appointed lawyers who represented indigent defendants violated the Sherman Act and the FTC Act by engaging in collective boycott in a wage dispute); Arizona v. Maricopa Cty. Med. Soc'y, 457 U.S. 332, 348-49 (1982) (holding that doctors who collectively set insurance reimbursement 
suggests the Supreme Court has been somewhat more forgiving when buyers engage in collective action..$^{95}$ The Justice Department's Healthcare Guidelines seem an apt example of the disfavored treatment of collective actions by sellers.

To be sure, there can be benefits from integration of medical practices, including a sharing of patient records or the development of sound treatment protocols. Treatment protocols, however, can force physicians to comply with a regimen that is profitable but not necessarily effective or cost efficient. In some cases, these protocols may perversely undermine treatment in areas where experimentation may be legitimate and where medical science has not reached a clear consensus. In other cases, the coordination may result in doctors choosing a form of treatment that is more profitable for the practice but less advantageous for the patient.$^{96}$ For example, a policy that encourages or requires participating doctors to use expensive treatments when equally or more effective treatments are available, or refuses to allow a doctor to deal with more than one health condition during a single visit.

Other benefits from an integrated practice might be achieved in ways that do not penalize the small practice. For example, sharing of patients' records can be efficient and advantageous to both the doctor and patient. But record sharing should not be confined to the limits of an integrated practice. A better solution might facilitate universal sharing of records among all medical professionals, regardless of their affiliation with a particular practice.

The Guidelines were not intended to discriminate against small medical practices. Unfortunately, that is one of their effects. In seeking a solution for the inequality of bargaining between doctors, on the one

fees for various medical procedures committed a per se violation of the Sherman Act).

95. See, e.g., Nw. Wholesale Stationers, Inc. v. Pac. Stationery \& Printing Co., 472 U.S. 284, 298 (1985); United States v. Topco Assocs., Inc., 405 U.S. 596, 61011 (1972) (holding that the joint purchasing and marketing arrangement violated Section 1, not because of efficient purchasing, but because of the territorial exclusivity accorded to member stores); Associated Press v. United States, 326 U.S. 1, 22-24 (1945) (holding that the joint procurement of news stories alone was not a violation of antitrust laws, but stringent entry rules were a violation). For additional analysis for the harsher treatment of joint selling when compared with joint purchasing, see Warren S. Grimes, The Sherman Act's Unintended Bias Against Lilliputians: Small Players' Collective Action as a Counter to Relational Market Power, 69 AnTitrust L.J. 195, 216-25 (2001); Masterman, supra note 6, at 1409-13.

96. See supra note 84 and accompanying text; Chad Terhune, Americans Waste $\$ 200$ Billion Every Year on Medical Tests They Don't Need, Experts Say, L.A. Times (May 25, 2017, 7:00 AM), http://www.latimes.com/business/la-fimedical-tests-20170526-story.html [https://perma.cc/VXX2-L5R8] ("Some experts estimate that at least $\$ 200$ billion is wasted annually on excessive testing and treatment."). 
hand, and oligopsonistic insurance providers and hospitals, on the other hand, the agencies have crafted a toxic and very much regulatory scheme that favors integrated medical practices over small group or solo practicing physicians. The Guidelines do not directly address the underlying problem that gave rise to doctor cooperative schemes: the increasing level of concentration among health insurers and hospitals with which doctors must deal.

The problems confronting the delivery of healthcare go well beyond merger policy. Still, core problems, such as concentration in ownership of hospitals and health insurance firms, can be traced to past failures in merger enforcement. Future merger policy, by lessening oligopsonistic dominance in the middle of the distribution chain, must be part of the solution. The choice to be a solo practitioner should be preserved for those doctors who prefer this way of practicing and patients who prefer this way of receiving medical care.

\section{Communications and Entertainment}

The digital age has fundamentally changed lives. The digital world is a central part of how people communicate, gather and share information, and find videos and other forms of entertainment. The digital communications business has fallen largely into the hands of large and oligopolistic firms, subject to considerable government regulation. Still, where competition reigns, there is less need for regulation. The cell phone industry is an example. Large firms dominate this industry, but there is sufficient competition and dynamism to provide consumers with meaningful service choices without heavy handed government regulation..$^{97}$

In other sectors of communication, competition has been lacking. ${ }^{98}$ High speed internet connections, for many consumers, are unavailable, ${ }^{99}$ or can be obtained only from a single provider. Subscription cable TValthough competitively threatened by video streaming through the

97. Press Release, Dep't of Justice, Justice Department Files Antitrust Lawsuit to Block AT\&T's Acquisition of T-Mobile (Aug. 31, 2011), https://www.justice. gov/opa/pr/justice-department-files-antitrust-lawsuit-block-att-s-acquisition-tmobile [https://perma.cc/L75D-D5QS] (calling T-Mobile "an important source of competition among the national carriers, including through innovation and quality enhancements").

98. See Susan Crawford, Captive Audience: The Telecom Industry and Monopoly Power in the New Gilded Age 9-10 (2013) (describing the monopoly risks arising from control of the internet pipeline by large, vertically integrated firms).

99. According to the FCC, 10 percent of all Americans lack access to $25 \mathrm{Mbps} / 3$ Mbps service. FCC, 2016 Broadband Progress Report, 31 FCC RCD. 699, 731 (2016). 
internet - continues to force consumers to purchase high-priced bundles containing mostly channels that they will never watch. ${ }^{100}$

There is creative atomism at the start of the entertainment distribution chain: authors, composers, artists, script writers, musicians, actors, and athletes develop and nurture their own skills. ${ }^{101}$ Although some work for large corporations, many remain tenaciously independent. A major issue for these creators is their ability to get programming to the public. To do so requires negotiating the hurdles of vertically integrated firms that control distribution and favor their own content or demand discriminatory ransom. ${ }^{102}$ The owners of independent channels, such as Wealth TV, have publicly complained of difficulties in obtaining distribution. ${ }^{103}$

Although some may view merger enforcement as vigorous under the Obama Administration, its record with respect to communications was spotty. The Justice Department and the Federal Communications Commission ("FCC") prevented AT\&T's proposed acquisition of TMobile, thereby preserving a maverick competitor, ${ }^{104}$ and also thwarted Comcast's proposed acquisition of Time Warner Cable. ${ }^{105}$ On the other hand, the agencies allowed, subject to conditions, Comcast's acquisition

100. See Warren S. Grimes, The Distribution of Pay Television in the United States: Let an Unshackled Marketplace Decide, 5 J. InT'L. Media \& EnT. L. 1, 3-4 (2013).

101. See supra Part II.B.

102. A 2007 study commissioned by the FCC found evidence that cable distributors are more likely to carry their own channels than those of rivals except in areas where there is adequate competition from satellite distributors. AUSTAN Goolsbee, Vertical Integration and the Market for Broadcast and Cable Television Programming 31 (2007). The study also found a lack of evidence of efficiencies in vertical integration of program providers and distributors. $I d$.

103. FCC, Fourteenth Report, 27 FCC Rcd. 8610, 8635 (2012). See also David Lazarus, Give Cable TV Subscribers More Freedom of Choice, L.A. Times (May 7, 2013), https:// http://articles.latimes.com/2013/may/07/business/lafi-lazarus-20130507 [https://perma.cc/GXF8-T38S] (stating the complaints of the Chief Operating Officer of Ovation TV, whose arts and entertainment channel had been dropped by distributor Time Warner Cable).

104. See Press Release, supra note 97.

105. Press Release, Dep't. of Justice, Comcast Corp. Abandons Proposed Acquisition of Time Warner Cable After Justice Dep't and the FCC Informed Parties of Concerns (Apr. 24, 2015), https://www.justice.gov/opa/pr/comcast-corporation -abandons-proposed-acquisition-time-warner-cable-after-justice-department [https://perma.cc/LD9R-XPTV]. 
of NBC Universal, ${ }^{106}$ AT\&T's acquisition of Direct TV, ${ }^{107}$ and Charter's acquisition of Time Warner Cable. ${ }^{108}$ Despite well-intended conditions imposed on these transactions, the overall impact of these consolidations was increased oligopoly power in the distribution chain. ${ }^{109}$

Comcast's acquisition of NBC Universal resulted in vertical integration of the country's largest cable and Internet provider with one of the largest video content providers. Despite minimal horizontal issues in this merger, the combination has contributed to actual and potential strategic conduct that makes it more difficult for small content providers to get their video programming to consumers. ${ }^{110}$ Competition would be best served if all distributors of video programming, whether by cable subscription or internet streaming, were not vertically integrated into content supply. The fear that large distributors were not sufficiently neutral was the major impetus for net neutrality regulation. ${ }^{111}$ Comprehensive regulation might not be required if Comcast and other distributors had no conflict of interest in deciding which programming to carry. Competition is a more efficient

106. Press Release, Dep't. of Justice, Justice Dep't Allows Comcast-NBCU Joint Venture to Proceed with Conditions (Jan. 18, 2011), https://www.justice.gov/ $\mathrm{opa} / \mathrm{pr} /$ justice-department-allows-comcast-nbcu-joint-venture-proceed-conditions [https://perma.cc/WQ3S-BFT9].

107. Press Release, Dep't of Justice, Justice Dep't Will Not Challenge AT\&T's Acquisition of DirecTV (July 21, 2015), https://www.justice.gov/opa/pr/justicedepartment-will-not-challenge-atts-acquisition-directv [https://perma.cc/92MW$\mathrm{E} 2 \mathrm{CE}]$.

108. Proposed Final Judgment at 5-6, United States v. Charter Commc'n, Inc., No. 16cv-00759 (D. D.C. Apr. 25, 2016), https://www.justice.gov/atr/file/844851/ download [https://perma.cc/M2JV-ST7S] (permitting the merger but imposing certain restrictions on making video programming available to Internet providers).

109. Professor Kwoka's conclusion that non-divestiture remedies were notably ineffective in preventing price increases offers one reason for concern with these outcomes. KWOKA, supra note 82, at 156 ("Conduct remedies result in price increases of 12.81 percent, suggesting that these are largely ineffective in restraining postmerger price increases.").

110. See, e.g., Ryan Hatch, Yankees' Opening Day: YES Network, Comcast Dispute Rages On, NJ (Apr. 3, 2016), http://www.nj.com/yankees/index.ssf/2016/ 04/yes_network_comcast_dispute_rages_as_yankees_open.html [https:// perma.cc/DWP9-CDB2].

111. Proponents of Internet openness "fear that broadband providers might prevent their end-user subscribers from accessing certain edge providers altogether, or might degrade the quality of their end-user subscribers' access to certain edge providers, either as a means of favoring their own competing content or services or to enable them to collect fees from certain edge providers." U.S. Telecom Ass'n v. FCC, 825 F.3d 674, 690 (D.C. Cir. 2016) (citing Verizon v. FCC, 740 F.3d 623, 629 (D.C. Cir. 2014)). See generally Restoring Internet Freedom, FCC, www.fcc.gov/general/open-internet [https://perma.cc/U5AQ-CH6V] (explaining the FCC's ideas on the principle of "Open Internet"). 
and less onerous way to ensure that telecommunications firms serve the public interest, but competition can work only if mergers undermining a competitive structure are blocked.

In November 2017, the Justice Department filed suit to challenge AT\&T's proposed acquisition of Time Warner. ${ }^{112}$ The vertical issues posed by this transaction are very similar to those addressed in Comcast's 2011 acquisition of NBC Universal. This time around, the Antitrust Division - not satisfied with conduct remedies - insisted on a divestiture as a condition for permitting the transaction, and is now in litigation with AT\&T. The outcome of this case is uncertain, but the more aggressive effort to oppose vertical integration is amply justified by the record of abuses in this industry.

AT\&T and Direct TV were direct competitors in areas of the country served by AT\&T's U-verse fiber-optic cable. In allowing their merger, the Justice Department and FCC imposed as a condition that AT\&T commit to extending its system of fiber-optic cable, thereby providing high-speed Internet access, or at least a choice in obtaining that access, to more U.S. consumers. ${ }^{113}$ Obtaining more competition and choices in high-speed Internet access is a critical policy goal. Even if the FCC might reasonably trade more internet access for a reduction in competition in providing cable or satellite TV, one wonders whether this is a legitimate interpretation of the Clayton Act, which prohibits acquisitions which may reduce competition in "any market" and does not authorize trading competition in one market for another. ${ }^{114}$

Statutory interpretation aside, AT\&T's commitment to expand its fiber-optic network will be difficult to enforce and, by itself, likely will not lead to meaningful competition in high-speed Internet access. If the firm drags its feet in building out its network, there may be little in the way of sanctions that the FCC or the Antitrust Division can impose. This sort of regulatory decree is at odds with the principle that the preferred remedy is structural and with the preference for fixing the problem before the acquisition proceeds. ${ }^{115}$ Moreover, even if the fiber

112. Complaint, United States v. AT\&T, No. 1:17-cv-02511 (D. D.C. Nov. 20, 2017).

113. AT\&T Inc., 30 FCC Rcd. 9131, 9278 (2015).

114. Clayton Antitrust Act, 15 U.S.C. $§ 18$ (2012) (stating that "[n]o person engaged in commerce . . . shall acquire, directly or indirectly, the whole or any part of the stock or other share capital ... where in any line of commerce or in any activity affecting commerce . . . , the effect of such acquisition may be substantially to lessen competition, or to tend to create a monopoly" but creating no exception for uncertain benefits in a different industry).

115. The Antitrust Division does not require that a merger remedy involve fixing the underlying competitive problem before the merger proceeds, but notes that "[a] fix-it-first remedy eliminates the Division's antitrust concerns and therefore the need to file a case." U.S. Dep't of Justice, Antitrust Division Policy Guide to Merger Remedies 26 (2004). 
network is completed, it will in many markets simply result in a duopoly. AT\&T will have a strong incentive to price-in parallel to its rival. Meaningful choice and meaningful price competition seem a pipe dream. ${ }^{116}$ A more comprehensive solution to providing affordable and high-quality high-speed Internet may require across the board regulatory or legislative relief. Meanwhile, the enforcers have given up competition in the subscription cable TV market for highly uncertain benefits in internet access.

Another content-stifling feature of video programming is the cumbersome bundles that are imposed on cable TV subscribers. These bundling practices are yet another example of mid-stream power, wielded at the expense of both creators at the beginning of the distribution chain and consumers at the end. The power is with oligopolistic content firms that require distributors to carry large bundles of their channels in the basic distribution tier, preventing distributors from offering a la carte choices. The coercive nature of the power these firms exercise over subscribers is reflected in a comment of a television executive who declared that customers would "give up food and a roof over their head before they give up TV." ${ }^{117}$ Concentration at both content and distribution levels makes it more difficult for an innovative maverick to offer consumers more choices.

The Antitrust Division has substantial expertise and interest in competition in telecommunications services. The address by former Assistant Attorney General Bill Baer, focusing on the need for competition and neutrality among internet pipeline providers, was helpful. ${ }^{118}$ But more is needed. The goal of achieving clarity and certainty would be fostered by policy statements addressing telecommunications mergers and other related competition issues. Levels of

116. Under President Obama, the FCC sought to encourage local communities to build their own high-speed networks, even beyond the borders of their municipality, taking the position that state legislation obtained by incumbent monopolists to block such development is preempted by the FCC's statutory authority. Incumbent internet service providers, who did not relish the competition, successfully challenged the FCC in court. See Press Release, FCC, Chairman Wheeler Statement on Municipal Broadband Court Decision (Aug. 10, 2016), http://transition.fcc.gov/Daily_Releases/Daily_Business/2016/ db0810/DOC-340738A1.pdf [https://perma.cc/LM9P-X7NA].

117. Meg James, Fox's Chase Carey Calls a la Carte Programming 'a Fantasy', L.A. Times (Aug. 8, 2013), http://articles.latimes.com/2013/aug/08/entertainment/ la-et-ct-foxs-chase-carey-calls-ala-carte-a-fantasy-20130808 [https://perma.cc/ 6LJ7-38JS]. A younger generation of cord cutters or never corders put pressure on cable TV distributors and programmers to offer more choices. The anticompetitive bundling practices of the industry, however, have endured for decades and may continue for many more years. See Grimes, supra note 100.

118. See Bill Baer, Assistant Attorney Gen., Dep't of Justice, Video Competition: Opportunities and Challenges 6-8 (Oct. 9, 2015), https://www.justice.gov/ opa/file/782401/download [https://perma.cc/F2S8-CL25]. 
concentration that may be tolerable in some industries are objectionable in a service and creative component industry so vital to consumers. Vertical integration that may be relatively unproblematic in some industries is likely to be troublesome when providers of popular content wield such leverage over distributors.

\section{Why Small Firms Thrive in the Beer \& Wine INDUSTRIES}

A relatively open distribution system can be critical for new entry and entrepreneurial choice. The beer and wine industries provide a compelling example. Both of these industries involve a creative component and winemakers, like farmers, are often growers. Small craft brewers and winemakers have enjoyed a strong resurgence. Antitrust enforcement, however, may have had little to do with protecting the opportunities of new entrants in these industries.

During the populist enforcement era of the 1960s, the Justice Department was aggressive in challenging beer mergers, among them an acquisition that would have created the nation's fifth largest brewer with 4.49 percent of the national market. ${ }^{119}$ The Government, successful in the Supreme Court, argued that in Wisconsin, the merger would have created the largest brewer with 24 percent of the market. ${ }^{120}$ This state market was harshly criticized as gerrymandered and inconsistent with market realities. ${ }^{121}$ Attention to concentration at the state level was consistent with state regulatory control and might have created a more favorable distribution platform for the subsequent emergence of craft brewing, but that was not to be. As merger enforcement standards were relaxed, multiple mergers produced today's highly concentrated beer industry. Two firms, Anheuser-Busch InBev and Miller Coors, had 70 percent of the beer sales in the United States as of $2016 .{ }^{122}$

Notwithstanding relaxed merger policies that produced a tight oligopoly, the craft beer revolution was enabled by strict state control over vertical integration. The 21st Amendment to the Constitution

119. United States v. Pabst Brewing Co., 384 U.S. 546, 550 (1966).

120. Id.

121. Kenneth G. Elzinga \& Thomas F. Hogarty, The Problem of Geographic Market Delineation in Antimerger Suits, 18 Antitrust Bull. 45, 81 (1973).

122. Press Release, Dep't of Justice, Justice Dep't Requires Anheuser-Busch InBev to Divest Stake in MillerCoors and Alter Beer Distrib. Practices as Part of SABMiller Acquisition (July 20, 2016), https://www.justice.gov/opa/pr/justicedepartment-requires-anheuser-busch-inbev-divest-stake-millercoors-and-alter-

beer [https://perma.cc/2JK3-WJAQ]. Molson, as a result of the divestiture required by the Antitrust Division, is the majority stakeholder of all of Miller's US operations. Id. 
repealed prohibition and gave each state control over the production and sale of alcoholic beverages. ${ }^{123}$ At that time, many states adopted a mandatory three-tier system, prohibiting vertical integration of producers, distributors, and retailers. ${ }^{124}$ Maintaining independently owned distributors makes it more difficult for powerful producers to lock up distribution. There may be other advantages that explain the growth and survival of small producers, but the open availability of distribution channels is an important part of this story. While distribution was not open in all states, the three-tier system was sufficiently rooted to enable the craft beer resurgence over the past two decades.

Small and regional breweries - called microbreweries-now control roughly 14 percent of the U.S. market by volume. ${ }^{125}$ Unlike farmers or ranchers, microbrewers typically do not grow or raise their own ingredients, but exercise their craft as processors. To have a chance to distribute efficiently, such brewers require access to effective distribution, particularly when a brewer hopes to reach a market beyond its home state. ${ }^{126}$ Even in states in which dominant brewers cannot own

123. U.S. Const. amend. XXI.

124. The ABInBev/SABMiller Merger and the State of Competition in the Beer Industry: Hearing Before the Subcomm. on Antitrust, Competition Policy and Consumer Rights, S. Comm. on the Judiciary, 114th Cong. 1, 3 (2015) (statement of Bob Pease, Chief Executive Officer, Brewers Association) (noting that ABInBev owns wholesalers in California, Colorado, Hawaii, Massachusetts, New York, Ohio, Oklahoma, Oregon, and Washington). Only fifteen states allow beer producers to own distributorships. Id. at 2 .

125. Stephen Wilmot, Craft Beer Slowdown Is No Help to Big Brewers, Wall St. J. (Aug. 30, 2016), https://www.wsj.com/articles/why-craft-brewing-slowdownwont-benefit-big-beer-1472187785 [https://perma.cc/UUA2-88ZT] (reporting that craft brewers continue to grow but at a slower rate). At the beginning of 1980, there were about ten microbreweries, but by 2016, there were 3,132. Victor J. Tremblay \& Carol Horton Tremblay, The U.S. Brewing Industry: Data AND ECONOMIC ANALysis 103 (2005); Number of Breweries, BREwERS Ass'N, https://www.brewersassociation.org/statistics/number-ofbreweries/ [https://perma.cc/6UB8-WEVJ] (last visited Sept. 12, 2017).

126. The repeal of prohibition gave states the authority to regulate the production and sale of alcoholic beverages. U.S. Const. amend. XXI. Many states responded with laws that prohibited a brewer from owning its own distributor. See, e.g., Heather Morton, Three-Tier Cheers!, St. Legislatures Mag. (June 2015), http://www.ncsl.org/research/financial-services-and-commerce/three-tier-cheers635689375.aspx [https://perma.cc/P8UB-SEA3] (explaining that states have strengthened laws to keep distributors independent from producers); Andrew Gill, Craft Brewers Win Small Victory in Springfield, but the Real Winners are Distributors, WBEZ NEws (June 4, 2013), http://www.wbez.org/news/ culture/craft-brewers-win-small-victory-springfield-real-winners-are-distributors107514 [https://perma.cc/CFG7-VB9R] (explaining that in Springfield, IL, "brewers were prohibited from owning any interest in beer or liquor distributors"). 
distributors, a dominant brewer may pressure independent distributors to exclude or disfavor smaller rival brewers.

In permitting Anheuser Busch InBev's acquisition of Miller Brewing, the Antitrust Division imposed a divestiture remedy to address horizontal concentration and a conduct remedy designed to protect microbrewers' access to independent beer distributors. ${ }^{127}$ The decree prohibits Anheuser Busch from engaging in certain loyalty or discount programs that discourage independent beer distributors from doing business with other brewers and requires Anheuser Busch not to acquire other brewers or distributors without allowing for advance review by the Antitrust Division. ${ }^{128}$ The sensitivity the Division showed to distribution issues affecting microbrewers was constructive but insufficient. ${ }^{129}$ Whether the conduct remedy will be effective in preventing the large firm's future exclusionary treatment punishing smaller rivals is an open question. ${ }^{130}$

The real lesson from the Anheuser Busch/Miller acquisition may be a failure in past merger enforcement. Consider an industry in which, instead of a 70 percent dominance by two firms, there are eight firms that share roughly 80 percent of the U.S. market. In such an industry, issues of vertical integration are far less troublesome. If one or more of these eight firms decided to acquire its own distributors, there is much less risk that the firm would use its control of a distributor strategically to injure a microbrewer. To the contrary, with a share of 20 percent or less of the market, the firm is more likely to reach out to other brewers to offer them distribution, in this manner profiting from a greater share in the distribution market. Under these more competitive conditions, the market is more likely to self-regulate, and do so in a more effective manner than through merger conditions imposed on a powerful oligopolist.

The wine industry in the United States also benefits from the independent distribution system that grew out of the 21st Amendment. The largest three wine firms control roughly 46 percent of the US market, ${ }^{131}$ but the industry is relatively unconcentrated, with at least

127. See Press Release, supra note 122.

128. Id.

129. Given the problems in maintaining open distribution, the Department would have been justified in prohibiting Anheuser Busch/Miller from acquiring any craft brewer for a substantial period of years.

130. Kwoka found conduct remedies were largely ineffective in preventing price increases by the merged firm. KwOKA, supra note 82, at 156 .

131. Rob McMillan, State of Industry Wine Report 201642 (2016). 
one winery in each of the fifty states ${ }^{132}$ and a steady growth in the number of firms - an average increase of 7 percent per year in the ten years ending in 2012. ${ }^{133}$ While large firms dominate the low-price market, small and boutique firms have a large presence in the mid- and high-priced categories. ${ }^{134}$

Entry barriers are said to be high for the lower priced segment of the market because of the large investment needed in plant, equipment, vineyards, and advertising. ${ }^{135}$ But a much smaller investment can get a new winemaker into the mid or high-priced wine market. ${ }^{136}$ While some smaller wine makers sell their wine directly to retailers or end consumers, 90 percent of all wine flows through distributors. ${ }^{137}$ The largest twenty distributors have 75 percent of the market, with several hundred smaller distributors sharing the remainder. ${ }^{138}$

Although price competition seems to discipline the low-end market, for mid- and high-price segments, conditions of monopolistic competition prevail: each distinctive brand enjoys substantial pricing freedom. ${ }^{139}$ These conditions complement the availability of independent distributors and make it possible for new entrants to succeed and consumers to choose among an increasing number of local brands. These benefits will continue as long as merger policy, and antitrust enforcement more generally, preserves the availability of independent distribution for small wineries.

The beer and wine industries are examples of creative mid-level processing that can be efficiently performed by individual entrepreneurs or small firms. What is needed is lower thresholds for horizontal concentration among processors. To the extent that these thresholds have already been exceeded, strict rules on vertical integration are required to maintain open entry for small processors.

\section{The WAY ForWARD}

Stacy Mitchell describes a small, dedicated North Dakota pharmacist who operates a pharmacy serving a town with 500 residents.

132. James Thornton, American Wine Economics: An Exploration of THE U.S. Wine INDUSTRY 2 (2013).

133. Id.

134. Id. at 3 .

135. Id. at $3-4$.

136. Don Cyr et al., The Changing Size Distribution of California's North Coast Wineries, 9 J. Wine ECON. 51, 60 (2014).

137. Thornton, supra note 132 , at 3.

138. Id.

139. Id. at $185-86$. 
To reach a larger customer base, the pharmacist opened a telepharmacy ten miles down the road, making the drive once or twice a day to deliver prescriptions. ${ }^{140}$ The return on this sort of business model is unlikely to attract large chain pharmacies, but this entrepreneur may have been assisted by a 1960s North Dakota law that limits pharmacy ownership to those who are licensed pharmacists. ${ }^{141}$ Conventional antitrust wisdom would condemn this law as protectionist: it would seem to protect inefficient small pharmacies from competition by large pharmacy chains that operate in most of the rest of the country. But the North Dakota law apparently has had a pro-competitive effect. Mitchell cites evidence that North Dakota has lower prescription drug prices than its neighbor South Dakota, where chain pharmacies are allowed, and most of the rest of the United States. ${ }^{142}$

A credible explanation for this result is that, in most of the country, the majority of retail pharmacies are owned by a few large chains that, rather than compete on price, are tacitly following oligopolistic pricing policies that enhance their profits. North Dakota, it turns out, may be the beneficiary of apparently protectionist legislation that has prevented its pharmacies from falling into the hands of large oligopolists. In this manner, it has preserved competition among the many diverse pharmacy owners.

The North Dakota story is consistent with the central theme explored here. Preserving entrepreneurial choice, particularly important for industries in which small entrepreneurs are suited, serves a number of fundamental antitrust goals: (1) preserving efficiency; (2) preserving small players who are central to innovation; (3) improving the quality of life for both those who sell and those who buy; and (4) protecting democratic values by diversifying wealth and power.

The protectionist features of the North Dakota law do not rest comfortably with competition law. That state's experience, however, highlights the inadequacies of a merger control policy that allows mergers to tight oligopoly. In particular, enforcement policies and court cases have given insufficient attention to oligopsony abuses that discriminate against small businesses or sole providers. The problem is acute in industries suited to small entrepreneurship, including those in which owner operation is a key advantage and those with a strong service or creative component. Such industries include, but are not limited to, agriculture, healthcare, and communications and entertainment.

To protect entrepreneurial choice for these industries, enforcement agencies must implement tightened horizontal merger thresholds. Concentration should be measured in geographic markets in which the small

140. Mitchell, supra note 1, at 498-99.

141. Id. at 499 .

142. Id. (noting that North Dakota, over a recent five-year period, had lower drug prices than South Dakota and the 13th lowest prices among the 50 states). 
business can reasonably market its product or service. In industries in which horizontal concentration is already high, enforcers must act assertively to prevent vertical combinations that provide both incentive and opportunity for exclusionary conduct by the vertically integrated firm. Where large vertically integrated firms already exist, vigorous enforcement against exclusionary vertical practices will help to preserve entrepreneurial choice. Antitrust should shun regulatory or enforcement decisions that punish reasonable collective responses of small players who confront oppressive monopsony power. 